\title{
NILAI-NILAI TOLERANSI DI MEDIA MASSA (Studi Terhadap Rubrik Opini Riau Pos)
}

\author{
Jarir Amrun $^{1}$ dan Khairiah ${ }^{2}$ \\ ${ }^{1}$ Sekolah Tinggi Agama Islam Negeri Bengkalis, Indonesia \\ ${ }^{2}$ Universitas Islam Negeri Sultan Syarif Kasim Riau, Indonesia \\ jarir.amrun@gmail.com
}

\begin{abstract}
Abstrak
Media massa pengaruhnya sangat besar bagi perkembangan pemikiran manusia. Menjamurnya media sosial (medsos), membuat manusia lebih sering berinteraksi dengan medsos daripada bertatap muka dengan sesama.Media cetak yang sekarang ini juga terbit dalam bentuk online dan disebarkan melalui media sosial tentunya beperan dalam membentuk sikap toleransi antarumat bersagama. Kajian media ini dikhususkan pada rubrik opini Riau Pos. Melihat nilai-nilai toleransi yang ada di rubrik opini Riau Pos. Beragam tulisan yang dimuat rubrik opini Riau Pos ini ternyata banyak mengandung nilai-nilai toleransi. Ada nilai toleransi antarumat beragama dan ada intern umat beragama.
\end{abstract}

\section{Pendahuluan}

Ada empat fungsi pers berdasarkan amanah Undang-Undang Pers, yaitu: (1) fungsi informasi, (2) edukasi, (3) hiburan, dan (4) kontrol sosial (Pasal 3 UU Pers No. 4 Tahun 1999). Realitasnya, dari keempat fungsi terebut, fungsi informasi dan hiburannya lebih dominan berbanding fungsi lainnya. Inilah yang menjadi titik perhatian penelitian ini, mengapa fungsi edukasi (pendidikan) terabaikan oleh pers (media massa). Namun, pendidikan yang diteliti dalam tulisan ini adalah nilai pendidikan toleransi, sehingga media berperan dalam membangun kearifan beragama.

Kini media massa tidak lagi sekadar lembaga untuk mencerdaskan atau hiburan semata, sekarang menjadi bisnis yang menguntungkan. Di sinilah alasan mengapa media melakukan perubahan mendasar. Tampilan media sangat dipengaruhi oleh rating pembaca atau pemasang iklan, sehingga muatannya terkadang mengabaikan nilai-nilai pendidikan. 
Media massa sebagai bisnis yang menggiurkan menyebabkan munculnya beragam jenis media massa dengan beragam bentuk dan konglomerasinya pasca reformasi (Formas Juitan Lase dan Adde Oriza Rio, 2004: 15-23). Pers seharusnya memberikan informasi guna mencerdaskan bangsa, namun sebaliknya, karena pertimbangan untuk meningkatkan oplah yang berujung pada peningkatan iklan (bisnis), apapun dilakukan, termasuk menyajikan berita yang merusak moral anak bangsa.

Di sisi lain, media merupakan bagian dari lingkungan yang mempengaruhi masyarakat, termasuk di dalamnya anak didik. Jika selama ini lingkungan yang mempengaruhi anak adalah orang tua (keluarga) dan lingkungan masyarakat, saat ini dengan adanya gadget dan

1 Dalam Undang-Undang Nomor 20 Tahun 2003 tentang Sistem Pendidikan Nasional Pasal 1 ditegaskan bahwa pendidikan adalah usaha sadar dan terencana untuk mewujudkan suasana belajar dan proses pembelajaran agar peserta didik secara aktif mengembangkan potensi dirinya untuk memiliki kekuatan spiritual keagamaan, pengendalian diri, kepribadian, kecerdasan, akhlak mulia, serta keterampilan yang diperlukan dirinya, masyarakat, bangsa, dan negara. handphone, maka media sangat dekat dengan anak. Akhirnya lingkungan yang paling dekat dengan anak tak lagi lingkungan real, tetapi alam maya (virtual)

Melihat posisi media sebagai lingkungan yang mempengaruhi pikiran dan perkembangan anak didik, maka peran media memiliki posisi urgen dalam membentuk karakter.

Pendidikan karakter akhir-akhir ini menjadi perbincangan yang hangat, ini dikarenakan masalah moral bangsa yang terus terkikis. Di sinilah munculnya undang-undang pendidikan yang memuat tentang beberapa karakter penting bagi anak diri. ${ }^{1}$ Pendidikan karakter dianggap sesuatu yang diabaikan selama ini, karena pendidikan baru menghasilkan orang yang cerdas, namun minus karakter yang baik. Tak heran jika

Selanjutnya dalam Pasal 3 ditegaskan bahwa pendidikan nasional berfungsi mengembangkan kemampuan dan membentuk watak serta peradaban bangsa yang bermartabat dalam rangka mencerdaskan kehidupan bangsa, bertujuan untuk berkembangnya potensi peserta didik agar menjadi manusia yang beriman dan bertakwa kepada Tuhan Yang Maha Esa, berakhlak mulia, sehat, berilmu, cakap, kreatif, mandiri, dan menjadi warga negara yang demokratis serta bertanggungjawab. 
seorang yang berpendidikan tinggi terjebak dalam lingkungan korupsi atau tindakan amoral lain.

Namun demikian, sejatinya tidak hanya lembaga pendidikan yang bertanggungjawab menangani hal tersebut. Lingkungan juga memiliki peranan yang cukup besar dalam membentuk jati diri dan perilaku anak bangsa. Lingkungan yang dimaksud di sini, salah satunya media. Sebab dalam era kemajuan teknologi informasi dan telekomunikasi sekarang ini, salah satu faktor yang berpengaruh sangat besar dalam pembangunan atau sebaliknya juga perusakan karakter masyarakat atau bangsa adalah media massa (Hurlock, 1978; Hurlock, 1991: 347). Khususnya media sosial yang mengambil beritaberita dari media massa online yang kini semakin digandrungi.

Di balik sisi negatif yang dimunculkan, media juga memiliki banyak sisi positif. Dalam media menyediakan berita-berita yang memang patut untuk diketahui masyarakat Indonesia, sebab media sebagai sumber informasi yang mudah didapat, hanya dengan tekanan jempol langsung akses.
Misalnya, informasi yang bermanfaat adalah seputar masalah politik, pendidikan, kesehatan, agama, kearifan lokal, dan lainnya. Untuk itu pers harus pandai memilah berita yang layak atau tidak untuk diterbitkan atau ditayangkan, karena pada intinya, pers memiliki dampak positif dan negatif terhadap pembentukan karakter bangsa (Alo Liliweri, 1991: 85). Dalam media ada rubrikasi, yakni kolom atau opini, seperti di Riau Pos yang memiliki kolom opini, ini tentunya bermanfaat bagi publik.

Melihat berbagai peran media (termasuk peran edukasi) dan pengaruhnya pada masyarakat, maka perlu dikaji apa saja nilai-nilai toleransi di media massa, dalam penelitian ini case study Riau Pos. Melalui kajian ini diharapkan adanya terobosan dan alternatif model penanaman nilai-nilai pendidikan karakter melalui media massa, khususnya rubrik opini Riau Pos.

\section{Nilai-nilai Toleransi di Rubrik Opini Riau Pos}


"Were we born to love or to hate?". Demikian Prof. Dr. Alaiddin Koto mengawali tulisannya. Dia mengutip tulisan Prof. Dr. Raihani saat dikukuhkan sebagai guru besar. Tulisan ini menyikapi beberapa kasus konflik antaragama, konflik internal agama, yang selalu terjadi di negeri ini. Nilai-nilai agama bukan untuk kedamaian, namun sebaliknya malah memunculkan kebencian, dalam bentuk saling hujat, bahkan bentrok yang merugikan anak bangsa. ${ }^{2}$ Allah menciptakan manusia dalam keragaman, gunanya untuk saling mengenal dan berkasih sayang, bersinergi untuk kebaikan.

Kekhasan gaya tulisan Prof. Dr. Alaiddin Koto ini adalah mengawali dari fenomena di lapangan. Dia selalu berpijak dari realitas. Tulisan yang menarik itu memang berpijak dari hal-hal aktual di kehidupan seharihari.

${ }^{2}$ Terkait toleransi, Chaidir dalam menyindir manusia dengan perilaku hewan. Hewan saja memiliki toleransi sesama mereka. Selaku dokter hewan, Chaidir mengutip studi ilmiah terbaru yang menunjukkan bahwa hewan memiliki kualitas hidup, melebihi stempel yang selama ini diberikan oleh manusia. Hewan mampu bersikap baik saat hidup berkelompok. Bila mereka hidup dalam kelompok dan memiliki komunitas, mereka
Keberbedaan bukan untuk dipertembungkan, tetapi dirangkai menjadi laksana orkestra di mana masing-masing instrumen tetap dengan ciri dan kapasitasnya, namun bekerja sama melahirkan sebuah simponi yang menyuguhkan keindahan untuk siapa saja yang berada di sekitarnya di bawah komando seorang konduktor. Keberbedaan bukan untuk dilebur menjadi satu, tetapi untuk dirangkai menjadi hiasan warna warni bak pelangi di cakrawala yang biru (Alaiddin Koto, 2015: 4).

Konflik di negeri ini semakin tajam, diperlukan solusi agar tidak merusak tatanan kehidupan masyarakat. Di sinilah perlunya sumbangan pemikiran seorang intelektual, Alaiddin Koto, dalam memberikan tafsir nilai-nilai alQur'an kepada publik, bagaimana kita harus bersikap saat ini. Hujat-

bersikap baik satu sama lain. Mereka memiliki pergaulan. Sebagaimana bangsa manusia yang perlu berlaku sopan, saling menghormati, terkendali, bersikap ramah, dan berlaku baik antarsesama bila hidup dalam satu komunitas, hewanpun menunjukkan perilaku yang sama bahkan seperti disebut Balcombe, hewan memiliki tenggang rasa satu sama lain. Chaidir, Toleransi Binatang, Senin, 21 November 2016, 4. 
hujatan di media massa, bahkan di media sosialpun semakin meluas. ${ }^{3}$

Al-Qur'an menjelaskan bahwa manusia diciptakan Allah untuk mengabdi kepada-Nya (Q.S. 3: 191), dan untuk saling berinteraksi serta saling bersinergi (Q.S. 49: 13). Dua ayat ini mengingatkan kepada manusia sebagai makhluk agar menyembah Allah, dan dalam perbedaan itu untuk saling bersinergi, yakni menggapai ridha Allah. Nilainilai kasih sayang telihat pada tempat awal manusia diciptakan dalam kandungan, yakni rahim ibu. Kemudian dianjurkan bersilahturahim (menjalin kasih sayang).

Munculnya konflik biasanya disebabkan sikap "merasa yang paling benar", yang lain salah. Sebagaimana dijelaskan Imam Hanafi (2015: 4), bahwa Rasulullah pernah menemukan

${ }^{3}$ Samsul Nizar menjelaskan konfik bukan hanya di dunia nyata, tetapi di dunia maya. Yang lebih membahayakan lagi masing-masing kelompok saling menyerang dengan kata-kata kasar, seperti orang yang tak berakhlak. Selain itu, situs-situs yang menyampaikan paham radikal semakin mudah ditemukan, maka jangan heran beberapa orang yang ikut paham radikal seperti ISIS mereka direkrut melalui media sosial atau situs-situs yang menyebarkan paham radikal.Tulisan Samsul Nizar ini terkait Penutupan 19 situs Islam yang sosok sahabat yang merasa paling benar. Lalu Rasulullah menyuruh Abu Bakar membunuh sahabat yang membahayakan tersebut, namun karena dilihat oleh Abu Bakar sahabat tersebut sedang rukuk, Abu Bakar pun batal membunuhnya. Berikutnya Umar diperintahkan membunuhnya, namun saat dilihat Umar sahabat tersebut sedang sujud, Umar enggan membunuhnya, namun saat Ali diperintah Rasulullah membunuh sahabat tersebut, ternyata dia telah pergi dari masjid. Kemudian Rasulullah berkata; "Jika kalian membunuh dia, umatku tidak akan terpecah setelah ini”. Hadis ini mengandung arti bahwa Rasulullah sebagai sosok yang paling menghargai sahabat saja tidak menyukai sikap merasa yang paling benar.

disinyalir mempromosikan paham-paham radikal oleh Kementerian Komunikasi dan Informatika. Samsul Nizar (2005: 4); Abdul Hamid Nasution (2015: 4). Tulisan lain yang terkait penutupan situs radikal yakni Donny Syofyan (2015: 4). Donny menawarkan kepada kawula remaja dan mahasiswa, perlu disuguhkan dengan materi-materi ajar pemikiran kritis, seni, sastra, dan filsafat. Para santri di banyak pesantren harus diekspos dengan nilai-nilai seni dan sastra sehingga tidak lagi melihat dunia luar secara hitam dan putih (halal dan haram). 
Imam Hanafi juga mengutip kata ana khairun minhu, atau "aku lebih baik dari ada dia”. Yakni kata pertama kali diucapkan oleh iblis untuk menunjukkan kesombongannya. Ungkapan iblis ini yang menjadi judul artikel Imam Hanafi. Kemudian Firaun menyatakan: Bukankah aku lebih baik dari Musa yang hina ini (Q.S. azZukhruf: 52) (Masrizal Al Husyaini, 204: 4).

Imam Ghazali mengingatkan umat manusia agar tidak terjebak pada dua jenis takabur, yaitu takabur dalam urusan agama dan takabur dalam urusan dunia. Takabur dalam urusan agama dibagi lagi menjadi dua; takabur karena ilmu dan takabur karena amal. Indikasinya, di antaranya ia merasa paling hebat, sehingga tidak mau mendengarkan orang lain. Pertama, ia merasa dirinya paling pintar dan merasa tidak memerlukan bantuan orang lain. Kedua, takabur karena amal. Contoh paling sederhana adalah sebagaimana cerita pada masa sahabat di atas, yang menunjukkan bahwa dirinya merasa lebih saleh daripada yang lain, merasa sudah paling sesuai dengan ajaran- ajaran Islam, sehingga di luar itu adalah anti-Islam.

Sikap merasa yang paling benar ini sekarang menjadi fenomena di dunia Islam, sehingga konflik pun bermunculan. Misalnya, munculnya ISIS yang menggegerkan dunia Islam, baik di Timur Tengah maupun di Indonesia, sebab mereka merekrut anggota dari seluruh Negara, termasuk dari negeri ini. Menurut Muhammad Hanif, aksi ISIS adalah bentuk daur ulang radikalisme yang pernah dilakukan kaum Khawarij. Bahkan Hanif menyatakan ISIS mirip bentuk kelompok Khawarij Azaariqah. Di antara pandangan ekstrim kelompok ini adalah: Semua orang selain mereka adalah kafir. Ciri mereka mengkafirkan umat Islam yang dianggapnya berbeda.

Melihat sepak terjang ISIS, jika benar mereka membunuh para wanita dan anak-anak, mereka menganggap kafir kaum muslimin yang berbeda dari mereka dan karena itu wajib diperangi, maka mereka adalah golongan baru daur ulang pemikiran dan ideologi khawarij azaariqah yang lama (Muhammad Hanif, 2014: 4; Mukhtaruddin, 2016: 4). 
Syamsuddin Muir menulis bahwa khilafah yang dibangun ISIS tidak sah. Syamsuddin mengutip pendapat Syaikh Yusuf al-Qaradhawi yang menilai aspek khilafah Islamiyah yang diproklamasikan ISIS itu tidak sah (Syamsuddin Muir, 2014: 4; Raja Dachroni, 2015: 4).

Abdurrahman Bukaily, seperti dikutip menjelaskan Helmi Basri (2015: 4) bahwa gerakan ISIS menjadikan senjata sebagai alat memaksakan ideologi dan kehendak, ISIS juga menjadikan perbedaan agama sebagai sebab perang. ISIS juga mengkultuskan pendapat sendiri dan memusuhi pendapat lain, serta dangkalnya pemahaman ISIS tentang Islam. Hal itu disebabkan ketiadaan ulama di kalangan ISIS.

Bukaily menilai ISIS itu menjadi penghalang gerakan revolusi dalam melawan kezaliman Syiah di Irak. ISIS juga menimbulkan fitnah besar dengan sikapnya yang mengkafirkan para penguasa dan ulama yang tidak mengikuti jalan mereka. Tindakan ISIS itu bisa melemahkan warga Islam Sunni yang ada di Irak dan Suriah. Sebab, sejak Amerika menguasai Irak dengan kekuatannya, maka Syiah Irak pun memerangi Islam Sunni atas bantuan Negara Syiah Iran.

Dalam konteks Indonesia, mengapa terjadi konflik agama? Agusyanto Bakar (2015: 4) mengulas kasus konflik agama di Tolikara, di Papua. Jika dilihat secara kasat mata, konflik ini tentunya akan memicu umat Islam di belahan dunia lain, sebab serangan terjadi saat umat Islam melaksanakan Shalat Idul Fitri, mereka diusir dan mushalla tempat melaksanakan shalat pun dibakar. Untung saja umat Islam tidak tersulut emosinya. Sebenarnya kasus ini bukan murni agama, tetapi kepentingan sempit dan subjektif (politik, ekonomi, dan lainnya) yang dibungkus dengan simbol-simbol agama.

Insiden Tolikara ini, menurut Hanna Ummu Dzaki, demikian nama penanya, membuktikan bahwa negara gagal melindungi warganya dalam beribadah. Mereka yang sudah melakukan aksi teror terhadap umat Islam tidak disebut teroris. Konflik antar-umat beragama seharusnya tidak terjadi. Negara tidak boleh lalai memberikan jaminan perlindungan 
kepada umat beragama untuk merayakan hari raya keagamaan. Pelaku harus ditindak tegas agar tidak menyebar ke lain (Hanna Ummu Dzaki, 2015: 4; Erdianto Effendi, 2016: 4).

Yuslenita menulis artikel Logika Minoritas dalam Mayoritas. Dia menjelaskan jumlah umat Islam di Inggris sudah mencapai angka tiga juta jiwa lebih atau sudah mencakup $5,4 \%$ dari total populasi Inggris, namun tidak mendapatkan hakhaknya untuk berlibur di hari besar umat Islam. Umat Islam di sana tidak ada yang protes, karena selaku minoritas kaum muslim tahu diri dan menghormati hak kaum mayoritas. Sementara umat beragama yang minoritas di Indonesia mereka sudah mendapatkan hak-haknya, seharusnya mereka bersyukur.

Di negeri di tempat saya bermukim saat ini, Inggris, tidak memberikan hari Jumat untuk libur kepada umat Islam. Penguasa dan masyarakat setempatpun tidak menjadikan Idul Adha, Idul Fitri, Isra' Mikraj, Maulid Nabi, dan 1 Muharram sebagai bank holiday atau libur nasional. Tidak seperti di
Indonesia, di mana kelompok minoritas mendapat hari-hari istimewa dan terus menerus ditambahkan hak-hak keistimewaannya sambil mengurangi keistimewaan kelompok mayoritas Muslim. Hari Ahad yang menjadi Minggu telah dilibur, walaupun Jum'at tidaklah menjadi hari libur kaum muslim (Yuslenita Muda, 2016: 4).

Pengalaman dosen Jurusaa Matematika Fakultas Sain dan Teknologi UIN Suska Riau ketika berada di Inggris menempuh pendidikan doktor ini sangat menjadi pelajaran bagi masyarakat Indonesia, khususnya Riau, bagaimana cara berinteraksi antar-agama. Tulisan sederhana dosen muda ini membangun kearifan beragama. Demikian juga di Nigeria, umat Islam di sana mengalami diskriminasi, sebagaimana dijelaskan Afriadi Putra (2014: 4), bahwa gerakan Boko Haram yang artinya pendidikan Barat Haram, adalah reaksi terhadap pemerintah Nigeria yang tidak memperhatikan penduduk muslim di wilayah Bornu. Perlawanan Boko Haram ini mendapat perhatian dunia 
internasional, termasuk PBB, padahal ketika pemerintah Nigeria memberlakukan ketidakadilan terhadap komunistas muslim di negeri tersebut tidak mendapat perhatian dunia. Jadi konflik di Nigeria bukan konflik agama, tetapi ketidakadilan dalam hal ekonomi, hukum dan lainnya, namun yang bergema di dunia internasional adalah konflik agama.

Toleransi antar-umat beragama dan intern umat terlihat saat Ramadhan, sebagaimana diungkap Fakhrunnas MA Jabbar (2015: 4) yang sudah melalang buana ke sejumlah negara. Dia mengumpamakan di negeri jiran Malaysia, rumah makan tetap buka, namun jika ditemukan umat Islam yang tidak puasa, mereka merokok, ngopi, makan dan lainnya di rumah makan, maka kena saman (denda).

Di Indonesia, sebagian daerah memberlakukan pelarangan rumah makan buka siang hari, boleh buka setelah siang hari, sebab saat itu umat Islam memerlukan makanan untuk berbuka, ternyata rumah makan yang buka sore hari rezeki (omzet) mereka melebihi dari bulan-bulan biasa
Ramadhan ternyata memberi berkah. Di internal umat Islam pun terlihat saling memberi (sedekah), sebab memberi makan orang yang berpuasa mendapat pahala sama dengan orang yang berpuasa. Toleransipun terlihat saat Hari Raya, masing-masing saling mengunjungi, tidak ada sekat yang membatasi perbedaan (Ahmad Supardi, 2014: 4).

Khususnya di Indonesia, Hari Raya Idul Fitri merupakan ajang saling memaafkan, silaturahmi dengan sanak keluarga. Bagi yang berada di kota, mereka merasa tidak berhari raya jika tidak pulang kampung. Mudik atau balek kampong adalah tradisi yang ada di Indonesia, Malaysia, dan Brunei Darussalam atau rantau Melayu.

$$
\text { Machasin (2016: 4) }
$$

menjelaskan bahwa mudik atau pulang kampung ternyata bukan merugikan, malah dinilai mengembangkan ekonomi. Jika selama ini ekonomi berputar hanya di kota, saat hari raya, ekonomi desa pun bergerak. Apa yang dijual di desa laku, sebab orang kota perlu oleholeh. Di sisi manajemen, ternyata mudik itu membangun semangat 
kerja, sebab usai bersilaturahmi dengan keluarga di kampung, kerjapun semakin meningkat. Dibandingkan yang tidak pulang kampung, mereka merasa murung karena tidak bisa berjumpa dengan keluarga. Bertemu dengan keluarga dan menjalin silaturahmi dengan sanak keluarga sangat besar manfaatnya bagi pembangunan bangsa ini. Nilai-nilai toleransi yang ada di kampung, kemudian ditularkan ke kota.

Dalam konteks membangun sikap toleransi dalam kehidupan ini tak mungkin dilakukan secara sepihak. Semua pihak yang terlibat, baik seagama maupun berlainan agama, dapat sama-sama mengukur dan menahan diri. Orang-orang Islam di Indonesia yang jumlahnya dominan selama ini sudah cukup teruji dalam mempertimbangkan keberadaan orang-orang berbeda agama (Fakhrunnas MA Jabbar, 2015: 4).

Amrizal (2015: 4) mengupas toleransi perspektif akhlak. Bahwa perbedaan itu sunatullah (sudah alami adanya), maka tidak perlu dipertentangkan. Demikian juga perbedaan dalam hal ijtihad, merupakan sesuatu yang lumrah. Bahkan jika benar mendapatkan dua pahala, jika salah, satu pahala. Nabi Muhammad sendiri memaklumi (mafhum) perbedaan itu, misalnya ketika Nabi Muhammad memerintahkan para sahabat “Janganlah seseorang Shalat Ashar kecuali di (perkampungan) Bani Quraizhah" (HR. Muttafaqun 'alaih). Ketika tiba waktu Shalat Ashar, sedangkan mereka masih berada di tengah perjalanan. Sebagian sahabat melaksanakan Shalat Ashar. Sedangkan sebagian mereka menundanya hingga sampai di perkampungan Bani Quraizhah. Ketika hal itu disampaikan ke Rasulullah, beliau tidak memberikan komentar apa-apa, dan tidak mencela kelompok manapun. Artinya, Rasulullah menghargai ijtihad para sahabat.

Ijtihad juga ditunjukkan ketika Khalifah Umar memimpin umat Islam, beliau banyak melakukan ijtihad. Para sahabat lainnya memaklumi, bukan menentang Umar. Di sinilah para sahabat mengedepankan akhlak dalam 
bergaul sesama mereka. Bukan melihat perbedaan mereka. Jika perbedaan yang dilihat, maka seluruh sahabat itu dari latarbelakang yang berbeda-beda. Namun, perbedaan itu menjadi potensi untuk membangun umat. Amr Bin 'Asy misalnya, sosok yang cerdas dan diplomat yang tangguh, namun kecerdasan itu digunakan untuk menaklukkan Mesir. Demikian juga Muawiyah Bin Abi Syufyan, kepiawaian beliau memimpin pasukan digunakan untuk menaklukkan negeri Syam, Damaskus. Masing-masing sahabat berbeda, namun akhlak yang mulialah yang menyatukan mereka.

Dalam konteks kekiniaan, perbedaan ynng ada, jangan membuat umat Islam lemah. Perbedaan yang sudah alami seharusnya digunakan untuk membangun, bukan sebaliknya, mencari perbedaan-perbedaan dan kemudian dipertentangkan dan menjadi paradigma berpikir sempit. Di sinilah peranan Kementerian Agama bagaimana dalam membangun kearifan internal umat beragama atau antar-umat beragama (Suhardi, 2017: 4). Namun, itu bukan tugas Kemenag sendiri, tetapi tugas kita semua, sebagai khalifah di muka bumi.

Ciri-ciri orang mukmin adalah tidak mau bersenda gurau yang tak perlu (ghibah). Ia selalu rendah hati, menganggap orang lain lebih baik darinya. Ia sibuk mengingat dan menghitung aib serta kekurangan dirinya, guna mengevaluasi dan memperbaikinya. Ia tidak sibuk dengan aib orang lain, jika ia dapatkan aib dari saudaranya maka ia tidak mendiamkannya tetapi memperbaikinya dan meluruskanya dengan cara yang baik dan bijaksana, tidak merendahkan saudaranya.

\section{Kesimpulan}

Rubrik opini Riau Pos ternyata mengandung banyak pesan-pesan nilai toleransi. Sebagai media yang banyak dibaca oleh khalayak ramai, tentunya bertanggungjawab membangun negeri. Sebagaimana mottonya, Bangun Negeri Bijakkan Bangsa. Yakni ikut membangun nilainilai kearifan beragama. Hal ini penting karena dengan ditanamkannya nilai-nilai toleransi itu, maka sikap saling menghormati antarumat beragama semakin kuat. 
Keragaman penduduk merupakan alat perekat dalam Indonesia, khususnya Riau, perlu sikap saling menghormati. Sikap terbentuk dari bacaan, yakni bacaan yang mengandung nilai-nilai toleransi. Di sinilah peran Riau Pos menyajikan bacaan-bacaan yang mengandung nilai-nilai toleransi.

Ada beberapa nilai toleransi yang terdapat rubrik opini Riau Pos, Pertama, bahwa keragaman itu sendiri sudah sunnatullah, karenanya tidak perlu dipertentangkan. Manusia yang hidup di bumi yang sama, dan matahari yang sama, lalu apakah kita dilahirkan untuk mencintai atau saling membenci. Demikian ulasan Prof. Dr. Alaiddin Koto di salah satu artikelanya.

Kedua, perbedaan pendapat di internal umat Islam sudah ada sejak masa Rasulullah SAW, namun Rasulullah sendiri tidak menyalahkan. Bahkan ketika Khalifah Umar bin Khattab menelurkan sejumlah ijtihad yang kontroversial, para sahabat mengikuti, sebab para sahabat lebih mengendepankan akhlak daripada perbedaan. Artinya, akhlak 


\section{Daftar Kepustakaan}

Abdul Hamid Nasution (2 April 2015). Media Islam dan Radikalisme. Riau Pos, 4.

Afriadi Putra (16 Mei 2014). Diskriminasi Muslim di Nigeria. Riau Pos, 4.

Agusyanto Bakar (30 Juli 2015). Kerusuhan Tolikara, Konflik Agama?. Riau Pos, 4.

Ahmad Supardi HS (4 Oktober 2014). Perbedaan Hari Raya Jangan Rusak Ukhuwah, Riau Pos, 4.

(3 Januari 2015). HAB dan Citra Negatif Kemenag. Riau Pos, 4.

Alaiddin Koto (22 Juni 2015). Untuk Apa Kita Dilahirkan. Riau Pos, 4.

Alo Liliweri. (1991). Memahami Peran Komunikasi Massa dalam Masyarakat. Cetakan 1. Bandung: PT. Citra Aditya Bakti.

Amrizal (24 April 2015). Akhlak Perekat Perbedaan. Riau Pos, 4.

Chaidir (21 November 2016). Toleransi Binatang. Riau Pos, 4.

Donny Syofyan (8 April 2015). Radikalisme dan Pendidikan Kritis. Riau Pos, 4.

Erdianto Effendi (2 Agustus 2016). Menjaga Kerukunan Umat Beragama. Riau Pos, 4.

Fakhrunnas MA Jabbar (20 Juni 2015). Membangun Sikap Toleransi di Bulan Suci. Riau Pos, 4.

Formas Juitan Lase dan Adde Oriza Rio. "Ekonomi dan
Diversifikasi Media Massa". Jurnal Interaksi III, no.1 (2014): 15-23.

Hana Ummu Dzakiy (27 Juli 2015). Intoleransi dan Disintegrasi. Riau Pos, 4.

Helmi Basri (10 April 2015). Reinterpretasi Jihad. Riau Pos, 4.

Hurlock, Elizabeth B. (1978). Perkembangan Anak. Alih bahasa dr. Med. Meitasari Tjandrasa. Edisi Keenam. Jakarta: Erlangga.

$\begin{array}{lr}\text { Perkembangan } & \text { Psikologi } \\ \text { Pendekatan Sepanjang } & \text { Rentang } \\ \text { Kehidupan). Edisi } & \text { Kelima. } \\ \text { Jakarta: Erlangga. } & \end{array}$

Imam Hanafi (30 Oktober 2015). Aku Lebih Baik daripada Dia. Riau Pos, 4.

Juprizal (27 Februari 2015). ISIS Mendiskreditkan Khilafah. Riau Pos, 4.

M. Mukhtaruddin (18 Januari 2016). Alternatif Pencegahan Terorisme. Riau Pos, 4.

Machasin (3 Juli 2016). Mudik (Bukan) Pemborosan. Riau Pos, 4.

Masrizal Al Husyaini (9 Mei 2014). Menganggap yang Paling Mulia. Riau Pos, 4.

Muhammad Hanif (29 Agustus 2014). ISIS dan Daur Ulang Radikalisme. Riau Pos, 4.

Samsul Nizar (7 April 2015). Blokir Situs Tak Mencerdaskan. Riau Pos, 4. 
Raja Dachroni (5 September 2014). Menyoal Perkembangan ISIS. Riau Pos, 4.

Suhardi (4 Januari 2017). Membangun Kerukunan Umat (Refleksi HAB Ke-71 Kemenag). Riau Pos, 4.
Syamsuddin Muir (12 September 2014). Khilafah ISIS Tidak Sah. Riau Pos, 4.

Undang Pers. (2006). Yogjakarta: Pustaka Pelajar.

Yuslenita Muda (22 Juni 2016). Logika Minoritas dalam Mayoritas. Riau Pos 